\title{
Cross-Sectional Analysis of the Determinants of Education Demand in Small-Scale Gold Mining Communities in Burkina Faso
}

\author{
Jean-Baptise M.B. Sanfo \\ Graduate School of International Cooperation Studies, Kobe University, 2-1 Rokkodai-cho, Nada-ku, Kobe, \\ Hyogo 657-8501, Japan
}

\begin{abstract}
This study investigates the determinants of education demand in small-scale gold mining communities in Burkina Faso. It investigates issues of low demand of education in small-scale gold mining communities, in relation to the current debate around natural resources being a curse for local communities. It highlights priorities of education demand and supply factors that investments from natural resources can target to turn the resource curse into a blessing for education. Probit regression was used for the analysis, as education demand is proxied by a binary variable. Results suggest that child characteristics, household, and education supply factors are important predictors of education demand in small-scale gold mining communities in Burkina Faso. However, households demand for education does not follow the traditional pattern that shows higher education demand for wealthier families. This study recommends then that interventions focus on "opening the eyes" of many parents for them to realize that education is a long-term investment.
\end{abstract}

Keywords: Education demand, gold mining communities, natural resource curse,

DOI: $10.7176 / \mathrm{JEP} / 10-12-15$

Publication date: April $30^{\text {th }} 2019$

\section{Introduction}

Developing human capital is important to sustain economic growth, as research found a positive relation between the level of human capital and long-term economic growth (Kyophilavong \& Ogawa, 2018). According to Dziechciarz-Duda \& Król (2013), investment in education yields returns to the individual, the community, and the country as a whole. To this respect, education systems in many countries put a lot of efforts into education development from an offer perspective, but also from a demand one (UNESCO, 2017). Recently, many developing countries implemented various policies to increase the demand for education (UIS \& UNICEF, 2015). For example, free basic education, meant to reduce the economic burden of education that households have to bear, expecting to boost education demand from them. The results of efforts of educations systems show an improvement in education demand, as there are increases in enrolments reported by many developing countries (Glewwe et al., 2011).

Despite previous gains in education demand, there are still many challenges that countries face, among which various education demand disparities due to many reasons specific to local contexts. For instance, there can be disparities due to local socio-economic or cultural context (Hilson, 2012). The local socio-economic context plays an important role in determining the demand for education. Ahlerup et al. (2017) argue that in a socio-economic context of gold mining boom, there may be less education demand, because the quick employment opportunities and financial inducement from gold drive parents and communities to neglect the education of their children. Sore \& Maiga (2015) seem to support this point of view, as they write that parents in small scale gold mining communities in Burkina Faso consider gold mining activities as a fast track to a higher socio- economic position relative to education, since education takes more time and has an uncertain outcome, and these attitudes push them not to enroll children.

A feature of natural resources (gold mining) for local communities is that they create a "spillover" that affects communities to a certain scale. There are mainly three channels through which this takes place, and each channel has a certain link with education (Aragon \& Rud, 2013; Santos, 2014). Specifically, these channels are the environmental channel, the local market economy channel and the fiscal channel. For example, the local market economy channel determines education demand, because it has direct links with an important factor of education demand, that is the labor market. The labor multiplier effect of gold mining makes unskilled labor abundent and usually well-paid (Moritz et al., 2017), a disincentive for individuals to seek education, since the return on the investment in education is low in such an environment (Marchand \& Weber, 2018). Thus, gold mining communities are in a context worth looking at, to understand the dynamics or determinants of the demand for education in such contexts.

Scholars such as Gylfason (2001) and Kouankap et al. (2017) argued that natural resources constitute a "curse" for local communities, that is communities that are rich in non-renewable natural resources experience a low level of development; education is one of the sectors that are affected by this "curse" (Black et al., 2005), but there many other scholars seem to agree that the "curse" can be turned into a blessing for education, if resources 
from natural resources invested in education target and prioritize its relevant determining factors. This study is significant as it highlights the priorities in terms of supply and demand factors of education. Investments from natural resources need to be channeled towards these priorities, to improve education demand in natural resource rich communities, a contribution to "turn the resource curse into a blessing for education". The case of Burkina Faso was chosen because it has not been studied yet, or at least from a national perspective, though the recent gold boom in the country seems to make it an interesting case.

\section{Overview of Small-Scale gold mining and Education in Burkina Faso}

Burkina Faso has a long history of gold mining activities, but gold mining was insignificant to the economy of the country until its recent boom. Currently, many industrial companies are in activity in the country, but small-scale gold mines still dominate the gold mining sector. From figure 1, it can be noticed that the number of gold mines in the country was 103 in 2006, and jumped to 416 in 2016. Within the same period, the number of small-scale gold mines were 101, but increased to 362 . Figure 1 also shows the relative high number of small-scale gold mining in the country, i.e. small-scale mines surpass by far large-scale ones. The Ministry of Mines of Burkina Faso regulates who can operate a small-scale mine or a large-scale one. For the operation of a mine, a license is required; however, many small-scale mines are still unregistered and are illegal. Because small-scale mining does not require much investments and is using rudimentary methods, many industrial mines are surrounded by smallscale mining activities. There government has been doing efforts to control the openings and operations of smallscale mines, but still does not have a complete control of the situation.

Small-scale gold mining communities rely on gold mining and related activities as the main source of livelihood, as farming yields less and less harvest for their subsistence (Sore \& Maiga, 2015). It is estimated in general that Burkina Faso people live with less than $\$ 1.90$ a day (World Bank, 2018); consequently, small-scale mining and related activities are seen by many people as a way to get out of poverty, attracting a large portion of the population. Despite so many people being involved in mining activities, gold production of small-scale gold mines is very low relative to industrial gold mines, for example it was only $3 \%$ of the total gold production of the country in 2012. Because some small businesses are operating "illegally", child labor is relatively higher in smallscale gold mining communities in Burkina Faso, which has potential negative implications for the schooling of working children (Zabsonré et al., 2016).

Efforts of the government of Burkina Faso have helped boost education access indicators from an overall perspective, but there are still many disparities throughout the country. Burkina Faso adopted the Education For All (EFA) agenda, and created strategies to reach its required objectives. The Plan Decennal de Developpement de l'Education de Base, PDDEB (Basic Education 10 years plan) was then adopted by the decree $n^{\circ} 99$ 245/PRES/PM/MEBA of 20 July 1999. It aimed at increasing the educational offer and reduce education disparities. Indeed, it contributed within a decade to double the number of enrolled children from 938238 in 2001 to 2205295 in 2010 (MoE), but still many issues to address. Following the end of the PDDEB, Burkina Faso adopted the Basic Education Development Strategic Plan 2011-2020, in French "Programme de développement stratégique de l'éducation de base (PDSEB)", to face challenges of its education system. One of those challenges are the low demand of education in small-scale gold mining areas. Figure 2 shows the level of education of children surveyed in 5 gold producing regions of Burkina Faso. The figure indicates that $53 \%$ of children of primary school age have never been to school, and only $39.2 \%$ are enrolled. Most of these children who are not in school would work on gold mining sites for many days a week, and those who are in school would work when they have no classes, for instance on weekends. Low education demand in gold mining communities is therefore a challenge that the government is facing.

\section{Literature review}

The demand for education is determined by household characteristics. Research on education and household background has shown a close relationship between family factors and primary education demand. Burke \& Beegle (2004) found that parents' educational background affects their decision to send children to school. Parents with education value education, see it from an investment perspective and are aware of its economic return or other positive externalities, then enroll their children and commit to their schooling. However, this investment decision is made by comparing the attractiveness of alternative future returns, in exchange for present investment in education (Burgess, 2016), precisely school fees and indirect cost of schooling. Hilson (2012) supports that the value that families place on formal education is a factor that affects the demand for education in gold mining areas. Furthermore, Osei-Tutu (2017) found that when the priority of families is to find a way to survive, the demand for education for their children is negatively affected. Indeed, many families cannot afford to pay for the education of their children due to poverty that they are undergoing, even in gold mining areas where many households are thought to be well off. Many previous authors support that the cost of education is an economic burden to many families, making them reluctant to send children to school (Emery et al., 2012; Morrissey et al., 2013). However, schooling decision also depends to some extent on children themselves. Parents may want to enroll children, but 
some of them would not go to school due to some reasons like peer pressure or personal motivation related to schooling. Redehey (2017) noted that children from elementary school age and above decide by themselves not to go school but rather work to get money. This also suggests that enrolling children is not just enough, there is a need of supervision of the children from parents.

The supply factors of schooling both in terms of quality and quantity also strongly determine the demand for education. Orazem \& King (2008) found that in developing countries, building more schools, equipping them and getting more teachers have contributed to an increase in education demand, seen through the increase of enrolments. Household demand for education depends on educational access and quality, because households have expectations and aspirations in sending children to school. When these expectations and aspirations of households are not met by the supply factors of education, households tend not to maximize on education of their children, that is they demand less education. For example, school distance in one of the issues often mentioned, that is there are not enough schools available for parents to send their children to, obliging children to walk a long distance to school. Vuri (2007) found a relationship between of the availability of and travel distance to school and the decision of parents to send their children to school or labor activities. In other words, when schools are distant, there is no motivation for parents to send children to school, because as the school is distant there can be risks for young children going to school, and also because a distant school requires higher transport costs that these parents may not be able to bear (Burgess et al., 2015).

\section{Methodology}

The main objective of the study is to examine how households in small-scale mining communities decide to send their children to primary school or not. In order to reach this objective, the following research questions are asked: 1. What are the household factors that determine schooling demand in small-scale gold mining communities?

2. To what extent do education supply factors determine the demand for schooling in small-scale gold mining communities?

\subsection{Theoretical Framework}

The theoretical framework that this study adapts is borrowed from the model of demand for schooling developed by Gertler and Glewwe (1990). This model has been used by previous authors to analyze the behavior of households in relation to the demand for schooling and schooling choices for their children (Kabubo-mariara \& Mwabu, 2007). In this model, households compare the direct and indirect cost of education to its future returns. When the advantages of sending children to school are outweighed by the disadvantages, parents choose not to send them to school. These advantages can be material benefits that parents derive from their investment in the education of their children, and also the satisfaction of having children who are educated and may be successful financially. Consequently, disadvantages are the associated costs to education, and they can be a heavy burden for parents.

The decision of the household to send a child to school is based on the derived utility from it, and is formalized as follows:

$\mathrm{U}_{1}=\mathrm{U}\left(\mathrm{S}_{1}, \mathrm{C}_{1}\right)+\varepsilon_{1}$

Where $S_{1}$ is the increment increase of human capital of the child resulting to another year of schooling, $C_{1}$ is the possible consumption or expenditure after spending both on direct and indirect costs of sending a child to school, and $\varepsilon 1$ is a random taste shifter. Alternatively, if the household decides to keep the child at home, the utility is denoted by:

$\mathrm{U}_{0}=\mathrm{U}\left(\mathrm{C}_{0}\right)+\varepsilon_{0}=\mathrm{U}\left(0, \mathrm{C}_{0}\right)+\varepsilon_{0}$

Where $\mathrm{C}_{0}$ is the consumption or expenditure that is possible with spending on costs associated to sending child to school, and $\varepsilon_{0}$ is the random taste shifter.

The household faces a budget constraint that can be denoted as follows:

$\mathrm{C}_{1}+\mathrm{TC}_{1}=\mathrm{C}_{0}=\mathrm{Y}^{\mathrm{d}}$

Where $\mathrm{TC}_{1}$ in the total cost incurred in sending a child to school, i.e. the indirect and direct cost of sending the child to school, and $\mathrm{Y}^{\mathrm{d}}$ is the disposable household income.

The utility maximization can be obtained by combining equation (1) and (2), while considering the constraint in equation (3). This can be denoted as follows:

$\mathrm{U}^{*}=\operatorname{Max}\left(\mathrm{U}_{0}, \mathrm{U}_{1}\right)$

Where $U^{*}$ is maximum utility, while $\mathrm{U}_{0}$ and $\mathrm{U}_{1}$ are conditional utility functions specified in (1) and (2), given the constraints in (3).

\subsection{Model specification strategy}

As already mentioned, the main objective of the study is to examine determinants of the demand for schooling decision from and a demand perspective (household) and an offer perspective (local school quantity and quality) in gold mining areas. As the demand for schooling is expressed by whether the household send a child to school 
or not, we have a binary outcome variable. Specifically, let $\mathrm{y}$ be the demand for education, $\mathrm{y}=1$ if a child is reported to be sent to school, and $y=0$ if otherwise. The solution to the utility maximization problem can give the probability that each alternative is chosen, that is send the child to school or not send the child to school (Kabubo-mariara \& Mwabu, 2007).

$\mathrm{U}_{1}=\beta_{1} \mathrm{~S}_{1}+\beta_{2} \mathrm{C}_{1}+\varepsilon_{1}$

Where $\beta$ s are parameters to be estimated. Given that the possible consumption possible after incurring for schooling expenditure can be expressed as $\mathrm{C}_{1}=\mathrm{Y}^{\mathrm{d}}-\mathrm{TC}_{1}$, Equation (5) can be expressed as:

$\mathrm{U}_{1}=\beta_{1} \mathrm{~S}_{1}+\beta_{2}\left(\mathrm{Y}^{\mathrm{d}}-\mathrm{TC}_{1}\right)+\varepsilon_{1}$

Where equation (6) is the utility the household derive from sending the child to school. The utility derived from not sending the child to school can be expressed as follows:

$\mathrm{U}_{0}=\beta_{2}\left(\mathrm{Y}^{\mathrm{d}}\right)+\varepsilon_{0}$

Parents will choose to send children to school when $U_{1}-U_{0}>0$ or $\left(\beta_{1} S_{1}-\beta_{2} T_{1}+\varepsilon_{1}-\varepsilon_{0}>0\right)$. Let $Z$ be the decision to send a child to school. The probability of $Z$ is as follows:

$\operatorname{Pr}[\mathrm{Z}=1]=\operatorname{Pr}\left[\left(\beta_{1} \mathrm{~S}_{1}-\beta_{2} \mathrm{TC}_{1}+\varepsilon_{1}>0\right)\right]$

The decision to send or not to send a child to school is influenced by some factors which affect the expected utility of the decision choice (Kabubo-mariara \& Mwabu, 2007): individual, household and community factors.

\subsection{Estimation strategy}

The method used by this study to estimate how households in small-scale mining communities decide to send their children to primary school is probit regression. The demand for education in this study has a dichotomous value, that is it takes the values 1 if the child in the data sample is enrolled, and 0 if otherwise. The probit model is specified as follows:

$\operatorname{Pr}(y=1 \mid \mathbf{X})=G\left(\beta_{0}+\beta_{1} \mathbf{x}_{1}+\ldots .+\beta \mathbf{x}_{\mathbf{k}}\right)=G\left(\boldsymbol{\beta}_{\mathbf{0}}+\mathbf{X} \boldsymbol{\beta}\right)$

Where $\mathbf{X}$ is $1 \times \mathrm{K}$ conditioning variables, and we take the first element of $\mathbf{X}$ to be unity. $\mathrm{G}$ is the standard normal cumulative distribution function (cdf), and takes a value between 0 and one for all real number $\mathrm{z}$ : $0<\mathrm{G}(\mathrm{z})<1$ for all $\mathrm{z} \in \mathrm{R}$. Equation (9) restricts the response probabilities between zero and one (Woolridge, 2010). In order to ensure that the response probabilities fall between zero and one, there are some non-linear functions in equation (9). $\mathrm{G}$ the standard normal cumulative distribution function (cdf) is expressed:

$$
\mathrm{G}(\mathrm{z}) \equiv \boldsymbol{\Phi}(\mathrm{z}) \equiv \int_{-\infty}^{z} \emptyset(v) d v
$$

Where $\emptyset(z)$ is the standard normal density

$$
\varnothing(z)=(2 \pi)^{-1 / 2} \exp \left(-z^{2} / 2\right)
$$

In binary response models like the probit model, caution is needed when interpreting the values of the coefficient parameters $\beta \mathrm{j}$. As the dependent variable y denotes a response between zero and one, the average of the explanatory independent variables represents no one in the sample. In addition, if the explanatory independent variables are continuous variables, the magnitude of the effect on the coefficients is not clear in the non-linear function. For these reasons, the following models are necessary to compute the values of the coefficient parameters.

$$
\begin{aligned}
& G\left[\widehat{\beta_{0}}+\widehat{\beta_{1}} \hat{x}_{1}+\cdots \hat{\beta}_{k-1} \hat{x}_{k-1}+\hat{\beta}_{k}\left(C_{k}+1\right)\right] \\
& -G\left(\widehat{\beta_{0}}+\widehat{\beta}_{1} \hat{x}_{1}+\cdots \hat{\beta}_{k-1} \hat{x}_{k-1}+\hat{\beta}_{k} C_{k}\right) \\
& n^{-1} \sum_{i}^{n}\left\{G\left[\widehat{\beta_{0}}+\widehat{\beta}_{1} \hat{x}_{i 1}+\cdots \hat{\beta}_{k-1} \hat{x}_{i k-1}+\hat{\beta}_{k}\left(C_{k}+1\right)\right]\right. \\
& \quad\left(\widehat{\beta}_{0}+\widehat{\beta}_{1} \hat{x}_{i 1}+\cdots \hat{\beta}_{k-1} \hat{x}_{i k-1}+\hat{\beta}_{k}\left(C_{k}\right)\right.
\end{aligned}
$$

Equations (12) and (13) are used to compute what is called the partial effect at the average (PEA) or average marginal effect (AME). The AME is what is used to interpret the results from the probit regression in a straightforward way.

\subsection{Gold Mining Communities identification strategy}

The concept of mining community is not clearly defined in the literature. However, a common identification strategy is based on spatial variations of residence of individuals in terms of distance to an active gold mine. Precisely, a gold mining community is determined based on its vicinity to a gold mine, as households within a chosen radius of that gold mine are considered as part of a gold mining community therefore exposed to the effect of mining activities. In this study, the identification strategy used information on geographical locations of households in the sample data, to which we match the presence (as indicated by longitude and latitude GPS location data) of an active gold mine in the vicinity. However, there is no consistency about the concept of vicinity in the literature. For example, while some studies consider individuals within a radius of $100 \mathrm{kms}$ as within the vicinity of a gold mine, some consider a radius of $20 \mathrm{kms}$ or $80 \mathrm{kms}$ (Aragon \& Rud, 2013). In this study, the geology of Burkina Faso and the knowledge of where individuals live allow to know where gold mines are and are likely to appear, and the study retained households within $20 \mathrm{kms}$ of radius of a small-scale mine or $40 \mathrm{kms}$ of radius of an industrial mine (a lot of small-scale gold mining activities are going on around industrial mines) as part of small- 
scale gold mining communities.

The database on GPS locations of gold mines were obtained from a private gold mining consulting company named MinEx Consulting, up-to-date as of September 2015. It is worth mentioning that no database will have $100 \%$ coverage, but MinEx estimates that its database for gold captures at least $99 \%$ of all giant-sized deposits $(>6 \mathrm{Moz}), 95 \%$ of the major deposits $(>1 \mathrm{Moz} \mathrm{Au}), 70 \%$ of the moderate deposits $(>100 \mathrm{Koz} \mathrm{Au})$ and $50 \%$ of the minor deposits $(>10 \mathrm{Koz} \mathrm{Au})$. The data contains the name or calling of each mine, its GPS information, the year it started being exploited (and it was closed if applicable), and its type (artisanal or industrial). Figure 3 gives a visual representation of the areas that were retained for this study.

\subsection{Data}

The dataset used for this study is an observational data, drawn from the Burkina Faso Household Living Standard Survey of 2014 "Enquête Burkinabe sur les Conditions de Vie des Ménages (EBCVM)". This is a survey carried out by the National Institute of Statistics and Demography, with a sample 10860 households. It is nationally representative, and the sampling technique follows the country administrative division, that is region, province, commune (municipality), and the lowest unit which is an enumeration area (EA). EAs have been designed considering the number of households living within each EA, and households in EA randomly selected. The dataset contains individual variables such a gender, age, working status etc., household variables such as household expenditure and living standard, and community variables such as rural or urban, quality and quantity indicators of the community level education. Since the study is interested in the household demand for schooling, only children of school age were drawn for the estimation. Precisely, official school age in Burkina Faso is between 6 and 18 , therefore those within the official age range of primary school students were retained. Table 1 presents the descriptive statistics of the data.

\section{Results and Discussion}

\subsection{Demand for Primary Schooling}

The results of the empirical analysis on the determinants of primary schooling is based on equation 9 . The computed average marginal effects of the estimation are presented on table 2 below. Measures of the goodness of fit of the models are given below the results of each estimation. From an overall perspective, it can be said that the model provides a reasonable fitness of the data.

\subsubsection{Child Characteristics}

Looking at child characteristics, there is a gender perspective of the demand for education in households. Males are favored, since they have $8 \%$ more likelihood of being enrolled relative to females. This is consistent with the findings of Lincove (2009) who state that there is a gender perspective in household investment in children's human capital. This suggests the traditional issue of keeping girls at home for household chores or other "women responsibilities", or the socio-cultural belief that there is no benefit of investing in the education of a girl, since she will belong to another family after marriage. Moreover, age is a factor that reduces the demand for education. In other words, as a child gets older, the probability of that child being enrolled decreases. Older boys have a higher probability of being in school than older girls. This is due to the fact that many households delay the enrolment of children (Burke \& Beegle, 2004), and when they have to make a choice, they favor boys, to the detriment of girls, reasons previously mentioned. Another explanation of the enrolment delay is that the older the children, the more likely parents require that they participate in income generating activities, since such activities are general abundantly available in mining areas due to the job multiplying effect of gold mining that increase job opportunities (Owusu \& Dwomoh, 2012). Unfortunately, because children under age 10 were not included in the variable related to labor in the dataset, this analysis cannot fully capture the effect of child labor on the demand for primary education. However, a child having slept in the household the previous night was used as a proxy of child labor, as a child having not slept in the household the previous night the survey was administered is likely to have joined some kind of income generating activities, since many of them require a long stay on gold mines and surrounding areas (Zabsonré et al, 2016). Results show that there was no statistical evidence to show any relation between this proxy and the demand for primary education.

\subsubsection{Household Characteristics}

When considering the characteristics of the household, education of the father was found to be statistically related to the demand for education in gold mining communities. Precisely, when the father has some education, it increases the likelihood of a child being in school. The education of the father increases the probably of girl being in school, while it does not influence that of boys. A previous study of Santos (2014) has already showed that fathers' education indeed affects the demand for education for their children in a gold mining community. Parents will value education, as they know more about its benefits and know that it is an investment that is safer than the relying solely on the local booming economy which may disappear someday.

The results of estimations are surprising in terms of household wealth and the demand for education. In the dataset used by this analysis, levels of income of households are divided in five groups (very rich, rich, neither 
rich nor poor, poor, and very poor). Due to a very small sub-sample size, the group of very rich households was dropped and neither rich nor poor households were used as the base group. Results show consistency of a negative demand for education across all four groups, even though some are no statistically significant. Poor households and rich households were found to be statistically related to less education demand. This finding confirms the view of previous scholars that natural resources constitute a mixed blessing or a curse for communities that are rich in natural resources (Gylfason et al., 1999; Gylfason, 2001; Manning, 2004). According to Araji (2014), human capital (education) is one of the sectors that are hit by the natural resource curse, because the economic effects of natural resources on individuals reduce the incentive to invest in human capital.

\subsubsection{Community Characteristics}

In terms of community characteristics, this analysis assessed those related to the community in general, and also those related to the education supply. Not surprisingly, being from an urban area increases a child's likelihood of being in school. This increase in the probability is consistent both for boys and girls. This finding confirms then the disparity urban/rural that characterizes Burkina Faso (Paré/Kaboré, 2012). Even though both a rural and an urban community may share the common point of being gold mining communities, urban mining communities are better off relative to rural ones in terms of primary schooling demand. Moreover, results of this analysis show a negative correlation between the probability of being in school and distance to the nearest usable road. The explanation of this finding is that many children (mostly in rural areas) still do not easily have access to appropriate roads or transportation to go to school, as some have to cross rivers or other dangers before reaching their school. Due to the fact that many gold mining communities are in remote or not easily accessible areas, children from these communities still have to walk a long distance to have access to a school. This is a disincentive for the demand of education, since no parent is likely let their children risk their lives on the way to school.

In small-scale gold mining communities, distance to the nearest primary school is not statistically associated to education demand, but rather distance to the nearest secondary school. The plausible explanation of this finding is that Burkina Faso focused more on policies related to education access at the primary level, and consequently many zones are characterized by a lack of secondary schools in the community. Knowing that the limit of schooling is not more than primary level, many parents would not enroll their children or would withdraw them from school, since it is not worth investing time and money in something with a dead end and will not pay off. Parents therefore consider the possibilities of education path beyond primary school, because this is how their can get a higher return in their investment in time and resources.

\subsection{Demand for Secondary Schooling \\ 5.2.1 Child Characteristics}

The demand for secondary education is also gender oriented, as boys were found to have a higher likelihood of being in school relative to girls. Just like for the case of primary education demand, households have a choice to make, and they usually make it according to such socio-cultural beliefs (Pilon \& Wayack, 2003). For example, many believe that boys will more likely help their own families when they have a job, while girls will likely help the family of their future husband. This is more observed in areas that give girls to marriage at a young age, and it is even known that the legal marriage age for girls in Burkina Faso is 16. It can be said that interventions aiming at reducing gender disparities in access to education have driven less disparities from an overall perspective (UNICEF, 2017), but results of this estimation show that the same case is not observed in small-scale gold mining communities. As children get older, they are less likely to be enrolled. Some authors suggest that as children increase in age, they have more potential to general income and support their families (Kabubo-mariara, \& Mwabu, 2007). However, there was no correlation found between secondary education demand and children working on gold mines, though number of hours of work was found to be positively related to education demand. This result is opposite to the view of Emery, Ferrer, \& Green (2012) who found that education demand reduces with the extent to which children work on mining activities. The number of hours of work can be associated to how much income these individuals get, since the more they work, the more likely they will generate more income. The income that they get is an economic addition to the household income, which contributes to a higher affordability of the cost of education, shown by a higher education demand.

\subsubsection{Household Characteristics}

Education of both parents is not associated with secondary education demand, but when the household head works on mining areas, this decreases the likelihood of the demand for education of boys. Work on mines is genderoriented, and since such jobs require a lot of physical strength, boys are more likely to be taken along when parents are going to work on mines (Platform for Labour Action, 2017). Usually, parents from small-scale gold mining communities stay many days on mining sites before returning home, which would not allow children to be in school. Wealth indicators of households show no correlation with the demand for secondary schooling. The age factor must be a reason, since when children get to this stage of their development, they tend to financially depend less on their families (Coulidiati-Kielem, 2016). In Burkina Faso, it is not surprising to see secondary school students who live alone and do not financially rely on their families. In such a context, the demand for secondary 
schooling depends more on the individual than the household. The results related to household composition, precisely members who are between 13-18 seem to confirm this. It was found that this group increases the likelihood of a child being in school, because such members of the family can generate an income that can even contribute to pay for the cost of education of other children. Botchwey \& Crawford (2016) support this point of view as they found that in small scale gold mining communities in Ghana, many children of secondary school age are financially induced by money from gold mining activities. Oppositely, young ones from age 6-12 may constitute a burden for the family in terms of the cost of education, and that is why this study found that as their number increases, the probability of education demand decreases.

\subsubsection{Community Characteristics}

Based on the results of the probit regression, urban gold mining communities are associated with less secondary education demand. This is a surprising finding, as many studies suggest that education demand is higher in urban areas relative to rural ones. However, taking the socio-economic context of gold mining activities going on in the community, there is usually an economic boom that is going on, combined with a relatively good living standard, factors that incentivize less demand for education from these individuals who with low level education and highlypaid jobs can take profit of urban good living conditions. Distance to the nearest secondary school and distance to the usable road are important determinants of secondary schooling demand. They are both affecting secondary schooling demand negatively. The same findings are supported by Burgess et al. (2015) who found that school distance is a factor that determine education demand. For the case of Burkina Faso, this finding can be explained by the fact that education demand policy focused mostly on increasing the number of primary schools, to the detriment of secondary ones. There are more and more children to complete primary education, but there are not enough secondary schools to take them, so they are obliged to put an end to their education. For the specific case of mining communities, since some of them are in remote areas, they may be left behind with no secondary schools available to go to at all. Even if parents want to enroll children, there are no schools to send them to.

\section{Conclusion and Policy implications}

This study investigated the determinants of household education demand in Burkina Faso, focusing on small scale gold mining communities. It analyzed household level factors which predict the demand for education in smallscale gold mining communities, as well as community level factors that also affect household demand for education, i.e. education supply factors. Because the factors that determine primary schooling demand are not necessarily the same compared to factors that determine the demand for secondary schooling, this study does not use exactly the same variables for primary education and secondary education analysis.

Results reveal that the gender of children and their age are predictors of the demand for primary and secondary education. Parental education, specifically father's education is an important determinant for primary education, but not for secondary education. Household wealth is important for only primary school demand in a "nontraditional" way, but not secondary school demand. However, family composition is a determinant of secondary education, as younger children constitute and weight against education demand, while older ones can contribute to increase education demand. About the results related to supply factors that determine education demand in small-scale gold mining communities in Burkina Faso, there are mixed results related to urban and rural disparities, since urban communities favor demand of primary schooling but not secondary schooling. As of community school factors, mostly the lack of secondary schools is a predictor of the demand of both primary and secondary education. Another predictor of the demand for education, is access to usable roads.

These results indicate that policies or interventions that aim at increasing the demand of education in smallscale gold mining communities may be directed towards households, but not focusing on the traditional belief that households do not demand education because they cannot afford it. Mabali \& Bonkeri (2014) indeed wrote that in gold mining communities, the demand for education may not be explained by the traditional household living standard. In the education demand theory of Gertler and Glewwe (1990), if the utility of sending a child to school is thought of as the economic return to education investment, in small-scale gold mining communities this return seems to be relatively low, and that is probably why wealth is negatively related to the demand for education. Programs for a higher demand in education are should try to "open the eyes" of many parents, to realize the shortsightedness of investing all their hope on gold mining and related activities, because natural resources are limited in stock, therefore a boom may be followed by the negative consequences of a bust (Jacobsen\& Parker, 2016). People without the necessary skills to adapt to a new economic trend will be left out. Education is what can help prepare individuals to face new unexpected environments.

This study has limitations however, and one is in the use of cross-sectional data. It just gives a snapshot of the situation at a given time, so findings may not necessarily be generalized on a long-term perspective. Moreover, because of a lack of availability of education quality variables in the data, this study could not assess how education quality supply factors determine the demand for education in small-scale gold mining areas. For example, teacher/student ratio, or availability of educational resources within schools are important factors that determine the demand for education. With availability of data, these limitations can be addressed by future studies. Another 
direction for future research is the cultural factors that determine the demand for education of households involved in gold mining activities. These factors also explain educational demand choices of households, and they are promising aspects to investigate in order to better understand education demand determinants in gold mining communities.

\section{References}

Ahlerup, P., Baskaran, T., \& Bigsten, A. (2016). Gold mining and education: a long-run resource curse in Africa? Working Papers In Economics, 666.

Aragon, F. M., \& Rud, J. P. (2013). Natural Resources and Local Communities: Evidence from a Peruvian Gold Mine. American Economic Journal: Economic Policy, 5(2), 1-25.

Araji, S. M. (2014). Essays on The Macroeconomic Effect of Natural Resource Rents Doctoral dissertation, The University of Wisconsin Milwaukee, Wisconsin

Black, D. A., McKinnish, T. G., \& Sanders, S. G. (2005). Tight Labor Markets and the Demand for Education: Evidence from the Coal Boom and Bust. Industrial and Labor Relations Review, 59(1), 1.

Botchwey, G., \& Crawford, G. (2016). Impact of Small-scale Gold Mining on Education and Livelihoods in Ghana. International Journal of Educational Leadership, 7(1).

Burgess, S. (2016). Human Capital and Education: The State of the Art in the Economics of Education. Bonn, Germany: IZA Discussion Paper 9885.

Burgess, S., Greaves, E., Vignoles, A., \& Wilson, D. (2015). What Parents Want: School Preferences and School Choice. The Economic Journal, 125(587), 1262-1289.

Burgess, S., Greaves, E., Vignoles, A., \& Wilson, D. (2015). What Parents Want: School Preferences and School Choice. The Economic Journal, 125(587), 1262-1289.

Burke, K., \& Beegle, K. (2004). Why Children Aren't Attending School: The Case of Northwestern Tanzania. Journal of African Economies, 13(2), 333-355.

Coulidiati-Kielem, J. (2016). Analyse transversale de l'effet des facteurs familiaux sur les acquis scolaires au primaire : résultats des évaluations nationales au Burkina Faso [Cross-setional Analysis of the Effect of Family Factors on Learning Achievements : Results of National Assessments in Burkina Faso] . Evaluer. Journal international de Recherche en Education et Formation, 2(3), pp. 11-31.

Dziechciarz-Duda, M., \& Król, A. (2013). On the Non-Monetary Benefits of Tertiary Education. Econometrics, 3(41), 78-94.

Emery, H., Ferrer, A., \& Green, D. (2012). Long-term consequences of natural resource booms for human capital accumulation. Industrial and Labor Relations Review, 65(3), 708-734.

Gertler, P. \& Glewwe, P. (1990). The willingness to pay for education in developing countries. Journal of public Economics, 42: 251-275.

Glewwe, P. W., Hanushek, E. A., Humpage, S. D., \& Ravina, R. (2011). School Resources and Educational Outcomes in Developing Countries: A Review of the Literature from 1990 to 2010. Nber Working Paper Series, 1755.

Gylfason, T. (2001). Natural resources, education, and economic development, European Economic Review, Vol. 45, 847-859.

Gylfason, T., Herbertsson, T., \& Zoega, G. (1999). A Mixed Blessing: Natural Resources and Economic Growth. Macroeconomic Dynamics, 3(2), 204-225.

Hilson, G. (2012). Family Hardship and Cultural Values: Child Labor in Malian Small-Scale Gold Mining Communities. World Development, 40(8), 1663-1674.

Jacobsen, G. D., \& Parker, D. P. (2016). 1The Economic Aftermath of Resource Booms: Evidence from Boomtowns in the American West. Economic Journal, 126(593), 1092-1128.

Kabubo-mariara, J., \& Mwabu, D. K. (2007). Determinants of School Enrolment and Education Attainment: Empirical Evidence from Kenya. South African Journal of Economics, 75(3), 572-593

Kouankap, D. N., Tah, C. B., Wotchoko, P., Magha, A., Chianebeng, J. K., \& Tene, D. J. (2017). Artisanal gold mining in Batouri area, East Cameroon: Impacts on the mining population and their environment. Journal of Geology and Mining Research, 9(1), 1-8.

Kyophilavong, P., Ogawa, K., \& Kim, B. (2018). Does Education Promote Economic Growth In Lao Pdr? Evidence From Cointegration And Granger Causality Approaches. The Journal of Developing Areas, 52(2).

Lincove, J. A. (2009). Determinants of schooling for boys and girls in Nigeria under a policy of free primary education. Economics of Education Review, 28, 474-484.

Mabali A., and Bonkeri B.(2014) "School attendance and poverty in an oil boom context in Chad", Etudes et Documents, $n^{\circ} 22$, CERDI.

Marchand, J., \& Weber, J. (2018). Local Labor Markets and Natural Resources: A Synthesis of the Literature. Journal of Economic Surveys, 32(2), 469-490.

Moritz, T., Ejdemo, T., Söderholm, P., \& Wårell, L. (2017). The local employment impacts of mining: an 
econometric analysis of job multipliers in northern Sweden. MIneral Economics, 30(1), 53-65.

Morrissey, T. W., Hutchison, L., \& Winsler, A. (2013). Family Income, School Attendance, and Academic Achievement in Elementary School. Developmental Psychology. Advance online publication. doi: $10.1037 / \mathrm{a} 0033848$

Orazem, P. F. \& King, E. M. (2008). Schooling in Developing Countries: The Roles of Supply, Demand and Government Policy," Handbook of Development Economics, Elsevier.

Osei-Tutu, J. (2017). Learning and Earning in the Context of Small-Scale Gold Mining: Examining the Compatibility of Schooling and Work in the Lives of Working Young People in Ghana. Journal of Educational and Social Research, 7(3), 95-108.

Owusu, E. E., \& Dwomoh, G. (2012). The Impact of Illegal Mining on the Ghanaian Youth: Evidence From Kwaebibirem District In Ghana. Research on Humanities and Social Sciences, 2(6), 86-92.

Paré/Kaboré, A. (2012). Disparités dans l'enseignement primaire et innovation pédagogique au Burkina Faso. Revue internationale d'éducation de Sèvres, 59, 71-82.

Pilon, M., \& Wayack, M. (2003). La Démocratisation de l'Enseignement au BurkinaFaso: que Peut-on en Dire Aujourd'hui? Cahiers d 'Études Africaines, XLII(1-2), 63-86.

Platform for Labour Action, . (2017). Child Labor in Gold Mining A Study on Bugiri and Moroto Districts of Uganda. Kampala: Platform for Labour Action.

Redehey, G. B. (2017). Youth in artisanal gold mining: Risks and i opportunities; the case of Asgede Tsimbla Woreda, Northwestern Tigray National Regional State, Ethiopia. International NGO Journal. 12(3), 22-28.

Santos, R. J. (2014). Not All that Glitters is Gold: Gold Boom, Child Labor and Schooling in Colombia. Documento CEDE, 2014(31).

Soré, Z., \& Maiga, A. (2015). Descendre dans Le Trou Plutot que D’aller en Classe : Les Sites Auriferes Artisanaux et Les Deperditions Scolaires Au Burkina Faso[Going down into the pit instead of going to class: Gold Mines and School dropouts in Burkina Faso]. Annales de l'Université de Ouagadougou, 20(A).

UNESCO, . (2017). "Accountability in education: meeting our commitments" Global Education Monitoring Report. Paris, France: UNESCO.

UNESCO Institute for Statistics (UIS) and UNICEF (2015). Fixing the Broken Promise of Education for All: Findings from the Global Initiative on Out-of-School Children. Montreal: UIS

Vuri, D. (2007). The effect of availability and distance from school on children's time allocation in Ghana and Guatemala. N.p.: University of Rome.

Wooldridge, Jeffrey M. 2010. Econometric Analysis of Cross Section and Panel Data. 2nd ed. Cambridge, MA: MIT Press.

World Bank, . (2018 ). Poverty \& Equity Brief Sub-Saharan Africa : Burkina Faso. N.p.: The World Bank. Retrieved from https://databank.worldbank.org/data/download/poverty/33EF03BB-9722-4AE2-ABC7AA2972D68AFE/Global_POVEQ_BFA.pdf

Zabsonré, A., Agbo, M., Somé, J., \& Haffin, I. (2016). Impact de l'exploitation minière sur les conditions de vie des populations au Burkina. PEP Policy Brief, 145. 
Figure 1: Evolution of the Number of Gold Mines in Burkina Faso

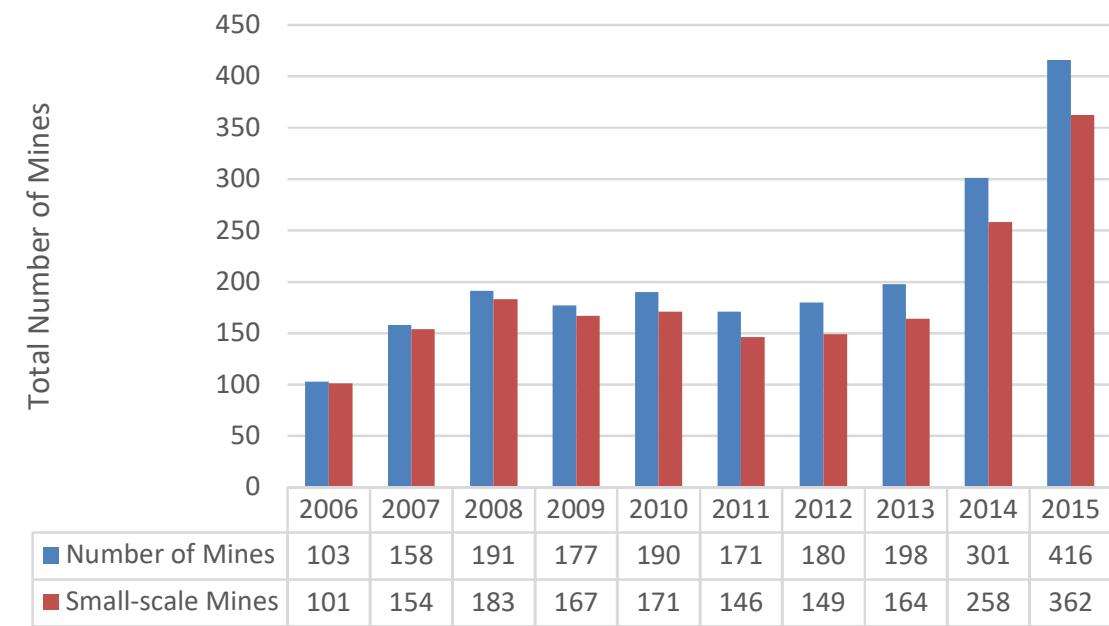

Created by Author based on Burkina Faso Ministry of Mines statistics

Figure 2: Level of education of 13294 children surveyed in 5 mining regions in Burkina Faso

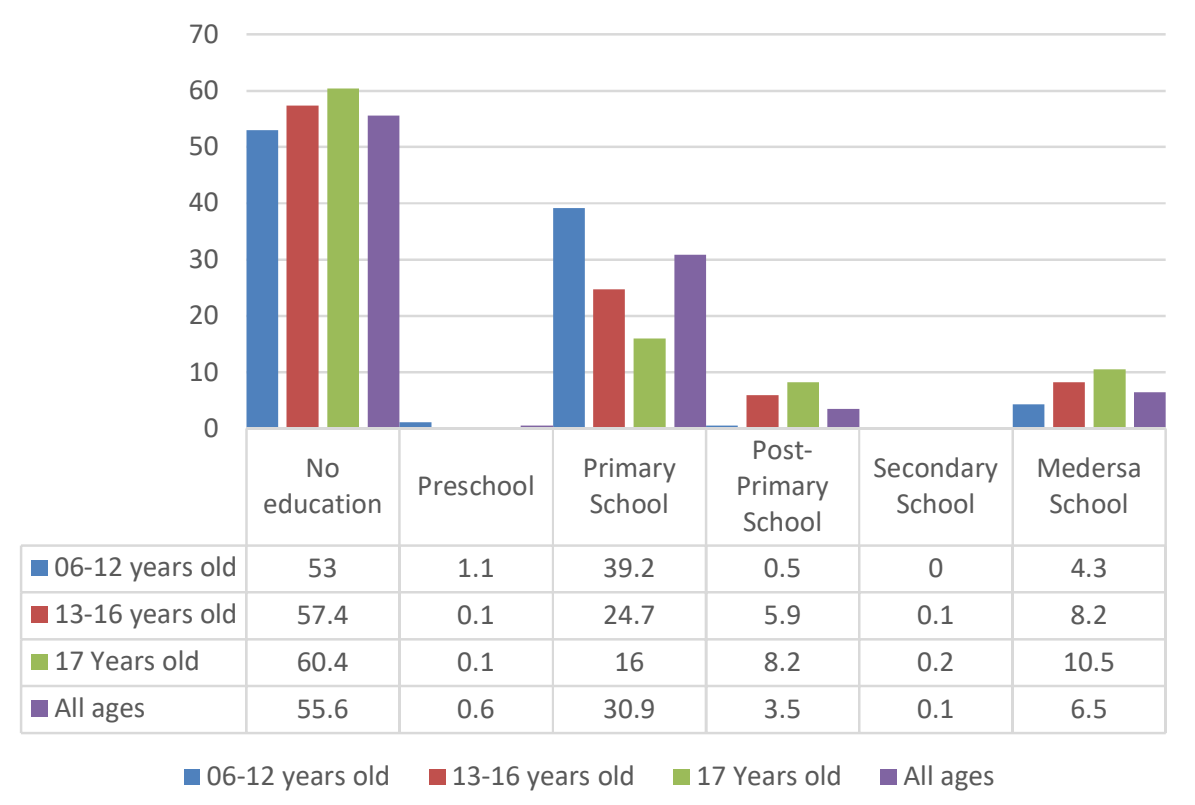

Source: Created by author based on Ministry of Welfare and National Solidarity, 2011 
Figure 3 Location of areas within the vicinity of a gold mine

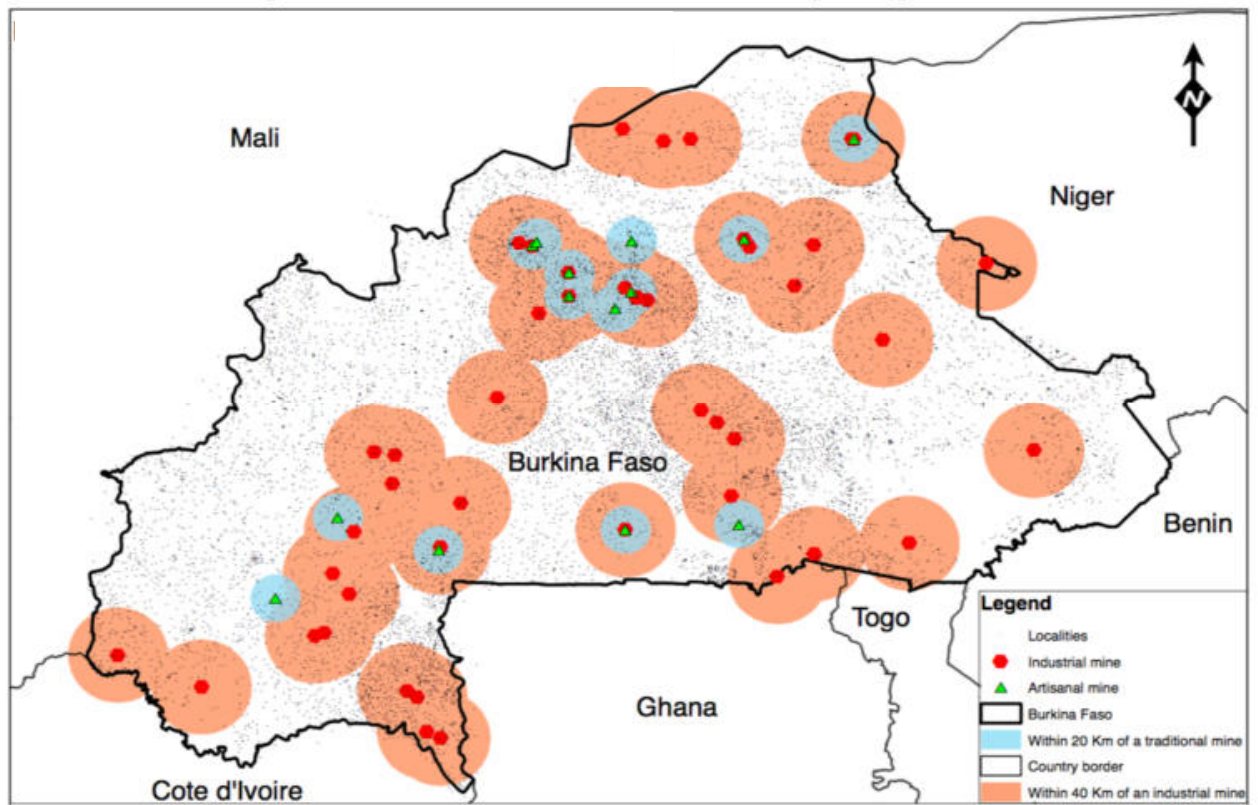

Source: Created by Author based on Burkina Faso Geography Institute data\& MinEx geocoded data

Table 1: Descriptive statistics

\begin{tabular}{|c|c|c|c|c|c|}
\hline Variable & Obs & Mean & Std. Dev. & Min & Max \\
\hline \multicolumn{6}{|l|}{ Outcome variable } \\
\hline Enrolled & 13291 & 0.572 & 0.495 & 0 & 1 \\
\hline \multicolumn{6}{|c|}{ Individual variables } \\
\hline Male & 13291 & 0.489 & 0.500 & 0 & 1 \\
\hline Age & 13291 & 8.868 & 2.001 & 6 & 18 \\
\hline Labor status & 13291 & 0.670 & 0.470 & 0 & 1 \\
\hline Revenue & 13291 & 59.651 & 189.163 & 0 & 5000 \\
\hline Health & 13291 & 0.069 & 0.254 & 0 & 1 \\
\hline \multicolumn{6}{|c|}{ Household Variables } \\
\hline Household size & 13291 & 8.112 & 4.036 & 1 & 22 \\
\hline Water Distance & 13291 & 1.691 & 1.152 & 1 & 5 \\
\hline Head education & 13291 & 0.150 & 0.357 & 0 & 1 \\
\hline Mother education & 13291 & 0.165 & 0.372 & 0 & 1 \\
\hline Head Job & 13291 & 0.202 & 0.402 & 0 & 1 \\
\hline Living Standard & 13291 & 2.089 & 0.655 & 1 & 5 \\
\hline Household income & 13291 & 100.571 & 2386.550 & 0 & 220000 \\
\hline \multicolumn{6}{|c|}{ Community Variables } \\
\hline Distance (Road) & 13291 & 2.300 & 1.605 & 1 & 5 \\
\hline Distance to School & 13291 & 1.716 & 1.188 & 1 & 5 \\
\hline Water Distance & 13291 & 1.691 & 1.152 & 1 & 5 \\
\hline Urban & 13291 & 0.277 & 0.448 & 0 & 1 \\
\hline
\end{tabular}

Created by Author based on Burkina Faso 2014 household survey 
Table 2: Marginal effects of determinants the demand for primary education

\begin{tabular}{|c|c|c|c|}
\hline VARIABLES & All & Boys & Girls \\
\hline \multicolumn{4}{|l|}{ Child characteristics } \\
\hline Boys & $\begin{array}{c}0.088^{* *} \\
(0.035)\end{array}$ & & \\
\hline Age & $\begin{array}{c}0.347 * * * \\
(0.091)\end{array}$ & $\begin{array}{c}0.316^{* *} \\
(0.125)\end{array}$ & $\begin{array}{c}0.411 * * * \\
(0.132)\end{array}$ \\
\hline Age square & $\begin{array}{c}-0.017 * * * \\
(0.005)\end{array}$ & $\begin{array}{c}-0.016^{* *} \\
(0.007)\end{array}$ & $\begin{array}{c}-0.021 * * * \\
(0.007)\end{array}$ \\
\hline Sleep in the household & $\begin{array}{c}0.051 \\
(0.150)\end{array}$ & $\begin{array}{l}-0.154 \\
(0.227)\end{array}$ & $\begin{array}{c}0.223 \\
(0.226)\end{array}$ \\
\hline \multicolumn{4}{|l|}{ Household characteristics } \\
\hline Father education & $\begin{array}{c}0.109 * * * \\
(0.041)\end{array}$ & $\begin{array}{c}0.070 \\
(0.057)\end{array}$ & $\begin{array}{c}0.157 * * * \\
(0.060)\end{array}$ \\
\hline Mother Education & $\begin{array}{c}0.215 \\
(0.208)\end{array}$ & $\begin{array}{c}0.125 \\
(0.338)\end{array}$ & $\begin{array}{c}0.240 \\
(0.266)\end{array}$ \\
\hline Father work on mines & $\begin{array}{c}0.123 * * \\
(0.051)\end{array}$ & $\begin{array}{c}0.094 \\
(0.066)\end{array}$ & $\begin{array}{c}0.172 * * \\
(0.081)\end{array}$ \\
\hline Rich household & $\begin{array}{l}-0.282^{*} \\
(0.164)\end{array}$ & $\begin{array}{l}-0.339^{*} \\
(0.204)\end{array}$ & $\begin{array}{l}-0.236 \\
(0.278)\end{array}$ \\
\hline Neither rich nor poor household & $\begin{array}{l}-0.091 \\
(0.067)\end{array}$ & $\begin{array}{l}-0.120 \\
(0.092)\end{array}$ & $\begin{array}{l}-0.057 \\
(0.098)\end{array}$ \\
\hline Poor household & $\begin{array}{l}-0.109^{*} \\
(0.062)\end{array}$ & $\begin{array}{l}-0.164^{*} \\
(0.087)\end{array}$ & $\begin{array}{l}-0.047 \\
(0.090)\end{array}$ \\
\hline Very poor Household & $\begin{array}{c}0.086 \\
-0.144\end{array}$ & $\begin{array}{l}0.339^{*} \\
(0.204)\end{array}$ & $\begin{array}{l}-0.166 \\
(0.210)\end{array}$ \\
\hline Number of adutls aged $>20$ & $\begin{array}{c}0.003 \\
(0.004)\end{array}$ & $\begin{array}{c}-0.002 \\
(0.006)\end{array}$ & $\begin{array}{c}0.008 \\
(0.006)\end{array}$ \\
\hline Number of children aged $<6$ & $\begin{array}{c}-0.002 \\
(0.005)\end{array}$ & $\begin{array}{l}-0.001 \\
(0.007)\end{array}$ & $\begin{array}{l}-0.001 \\
(0.006)\end{array}$ \\
\hline Number of children aged 6-12 & $\begin{array}{c}0.004 \\
(0.005)\end{array}$ & $\begin{array}{c}0.000 \\
(0.006)\end{array}$ & $\begin{array}{c}0.009 \\
(0.007)\end{array}$ \\
\hline Number of children aged 13-18 & $\begin{array}{c}0.006 \\
(0.006)\end{array}$ & $\begin{array}{c}0.008 \\
(0.011)\end{array}$ & $\begin{array}{c}0.006 \\
(0.008)\end{array}$ \\
\hline Community characteristics & & & \\
\hline Distance to Primary School & $\begin{array}{c}-0.002 \\
(0.016)\end{array}$ & $\begin{array}{l}-0.017 \\
(0.022)\end{array}$ & $\begin{array}{c}0.003 \\
(0.025)\end{array}$ \\
\hline Distance to Secondary school & $\begin{array}{c}-0.049^{* * *} \\
(0.015)\end{array}$ & $\begin{array}{l}-0.030 \\
(0.022)\end{array}$ & $\begin{array}{c}-0.061 * * * \\
(0.021)\end{array}$ \\
\hline Urban & $\begin{array}{c}0.179 * * * \\
(0.042)\end{array}$ & $\begin{array}{c}0.196 * * * \\
(0.059)\end{array}$ & $\begin{array}{c}0.155^{* *} \\
(0.061)\end{array}$ \\
\hline Distance to source of water & $\begin{array}{l}-0.005 \\
(0.015)\end{array}$ & $\begin{array}{c}0.019 \\
(0.021)\end{array}$ & $\begin{array}{l}-0.027 \\
(0.021)\end{array}$ \\
\hline Distance to usable road & $\begin{array}{l}-0.023^{*} \\
(0.013)\end{array}$ & $\begin{array}{l}-0.020 \\
(0.018)\end{array}$ & $\begin{array}{l}-0.027 \\
(0.019)\end{array}$ \\
\hline Log Likelihood & -4046.498 & -2028.684 & -2007.965 \\
\hline Pseudo R square & 0.147 & 0.136 & 0.173 \\
\hline Observations & 6788 & 3460 & 3328 \\
\hline
\end{tabular}

Standard errors in parentheses

$* * * \mathrm{p}<0.01, * * \mathrm{p}<0.05, * \mathrm{p}<0.1$ 


\begin{tabular}{|c|c|c|c|}
\hline VARIABLES & All & Boys & Girls \\
\hline \multicolumn{4}{|l|}{ Child characteristics } \\
\hline Boys & $\begin{array}{c}0.085 * * * \\
(0.011)\end{array}$ & & \\
\hline Age & $\begin{array}{c}0.076 \\
(0.053)\end{array}$ & $\begin{array}{l}-0.023 \\
(0.077)\end{array}$ & $\begin{array}{c}0.064 \\
(0.072)\end{array}$ \\
\hline Age square & $\begin{array}{c}-0.004 * * \\
(0.002)\end{array}$ & $\begin{array}{l}-0.001 \\
(0.002)\end{array}$ & $\begin{array}{l}-0.004 * \\
(0.002)\end{array}$ \\
\hline Working on mines & $\begin{array}{c}0.007 \\
(0.033)\end{array}$ & $\begin{array}{c}0.042 \\
(0.043)\end{array}$ & $\begin{array}{l}-0.045 \\
(0.048)\end{array}$ \\
\hline Daily hours of work & $\begin{array}{c}0.003 \\
(0.002)\end{array}$ & $\begin{array}{c}0.010 * * * \\
(0.004)\end{array}$ & $\begin{array}{l}-0.003 \\
(0.003)\end{array}$ \\
\hline \multicolumn{4}{|l|}{ Household characteristics } \\
\hline Father education & $\begin{array}{c}0.021 \\
(0.013)\end{array}$ & $\begin{array}{c}0.016 \\
(0.018)\end{array}$ & $\begin{array}{c}0.026 \\
(0.017)\end{array}$ \\
\hline Mother Education & $\begin{array}{l}-0.014 \\
(0.035)\end{array}$ & $\begin{array}{l}-0.001 \\
(0.054)\end{array}$ & $\begin{array}{l}-0.031 \\
(0.045)\end{array}$ \\
\hline Father work on mines & $\begin{array}{l}-0.025 \\
(0.016)\end{array}$ & $\begin{array}{c}-0.049 * * \\
(0.022)\end{array}$ & $\begin{array}{l}-0.011 \\
(0.022)\end{array}$ \\
\hline Rich household & $\begin{array}{c}0.042 \\
(0.127)\end{array}$ & $\begin{array}{c}-0.034 \\
(0.195)\end{array}$ & $\begin{array}{c}0.116 \\
(0.165)\end{array}$ \\
\hline Neither rich nor poor household & $\begin{array}{c}0.042 \\
(0.120)\end{array}$ & $\begin{array}{c}0.030 \\
(0.185)\end{array}$ & $\begin{array}{c}0.059 \\
(0.157)\end{array}$ \\
\hline Poor Household & $\begin{array}{c}0.056 \\
(0.120)\end{array}$ & $\begin{array}{l}-0.046 \\
(0.184)\end{array}$ & $\begin{array}{c}0.145 \\
(0.156)\end{array}$ \\
\hline very poor household & $\begin{array}{c}0.076 \\
(0.121)\end{array}$ & $\begin{array}{c}-0.034 \\
(0.187)\end{array}$ & $\begin{array}{c}0.160 \\
(0.159)\end{array}$ \\
\hline Number of children aged $<6$ & $\begin{array}{c}0.001 \\
(0.001)\end{array}$ & $\begin{array}{c}0.001 \\
(0.002)\end{array}$ & $\begin{array}{c}0.000 \\
(0.002)\end{array}$ \\
\hline Number of children aged 6-12 & $\begin{array}{c}-0.010 * * * \\
(0.001)\end{array}$ & $\begin{array}{c}0.002 \\
(0.002)\end{array}$ & $\begin{array}{c}-0.015 * * * \\
(0.002)\end{array}$ \\
\hline Number of children aged 13-18 & $\begin{array}{c}0.006^{* * *} \\
(0.002)\end{array}$ & $\begin{array}{c}0.011 * * * \\
(0.002)\end{array}$ & $\begin{array}{l}-0.000 \\
(0.002)\end{array}$ \\
\hline Community characteristics & & & \\
\hline Distance to Secondary School & $\begin{array}{c}-0.059 * * * \\
(0.004)\end{array}$ & $\begin{array}{c}-0.063 * * * \\
(0.006)\end{array}$ & $\begin{array}{c}-0.045^{* * *} \\
(0.006)\end{array}$ \\
\hline Urban & $\begin{array}{c}-0.149 * * * \\
(0.014)\end{array}$ & $\begin{array}{c}-0.160 * * * \\
(0.019)\end{array}$ & $\begin{array}{c}-0.127 * * * \\
(0.019)\end{array}$ \\
\hline Distance to source of water & $\begin{array}{c}0.000 \\
(0.005)\end{array}$ & $\begin{array}{l}-0.007 \\
(0.007)\end{array}$ & $\begin{array}{c}0.003 \\
(0.007)\end{array}$ \\
\hline Distance to usable road & $\begin{array}{c}-0.025^{* * *} \\
(0.004)\end{array}$ & $\begin{array}{c}-0.015^{* *} \\
(0.006)\end{array}$ & $\begin{array}{c}-0.032 * * * \\
(0.006)\end{array}$ \\
\hline Log Likelihood & -3615.05 & -1690.614 & -1847.468 \\
\hline Pseudo R square & 0.194 & 0.201 & 0.189 \\
\hline Observations & 6,503 & 3,081 & 3,422 \\
\hline
\end{tabular}

Standard errors in parentheses

$* * * \mathrm{p}<0.01, * * \mathrm{p}<0.05, * \mathrm{p}<0.1$ 